\title{
At Crossroads: Reflections on the Efficacy of the Southern African Development Community (SADC) in Conflict Resolution in Zimbabwe and the DRC
}

\author{
Article by Feddious Mutenheri \\ Texila American University \\ E-mail:feddious@gmail.com
}

\begin{abstract}
Since its formation in 1980, The Southern African Development Community (SADC) (formerly $S A D C C)$ has been confronted with a number of conflict cases within its membership. The conflicts include, but indeed not limited to, civil wars in Angola and DRC and political instability in Lesotho, Madagascar, South Africa and Zimbabwe. The Democratic Republic of Congo and the Zimbabwean conflicts are contemporary yet internecine test cases a propos the competence and relevance of SADC in providing the so-called "African solutions to African problems". SADC, through its various organs has been involved in the resolution of these conflicts. Nonetheless, SADC has found itself in intricate circumstances and perceptibly unsatisfactory principally as it dealt with Zimbabwe and the DRC. The paper traces the development of conflict in the DRC and Zimbabwe. It traces the historical performance of the SADC in conflict resolution in southern Africa. It is the aim of the paper to assess $S A D C$ performance in conflict resolution in the region, particularly in Zimbabwe and the DRC.
\end{abstract}

Keywords: SADC Efficacy, Conflict Resolution, Negotiation.

\section{Introduction}

Continued existence and relevance of organizations and institutions in general and SADC in particular, are predicated on their ability to effectively deliver on their aims and objectives. Failure to do so may spell doom or undermine the sustainability of such institutions. The effectiveness, efficiency and relevance of the Southern African Development Community in conflict resolution within the region have been put to test in Zimbabwe and the Democratic Republic of Congo. Arguably, SADC's failure to tackle these conflicts and oftentimes its droopy approach to solving these conflicts has raised many questions than answers on its relevance and more so its vigilance to deal with such. Often, skyscraping expectations had been placed in SADC to decisively consummate democratic transition in Zimbabwe. Conversely, SADC chose to be part of the crisis at least at the level of lack of progress there and its manifest bias by its officials in its decisions. In the DRC, SADC has been more of a spectator in the unfolding obdurate conflict rather than taking a leading role as the parent regional organization. SADC has had opportunities in both the countries to bring belligerents to the same table and recoup vanquished democracy in these scoundrel states. There is colossal need for reform in SADC's constitution, organs and policies, for it to be relevant in conflict resolution, peacebuilding and peacemaking in the region.

\section{The emergence of SADC}

In order to understand the performance of SADC in the resolution of conflicts within its region, it is very important to dissect its very origins. The genesis of SADC lies in the 1960s and 1970s, when the leaders of majority-ruled countries and national liberation movements coordinated their political, diplomatic and military struggles to bring an end to colonial and white-minority rule in southern Africa. The immediate forerunner to this organization was the Frontline States which was a very much informal grouping. This grouping was predicated on political and security concerns during the time. Its forerunner in the socio-economic realm was the Southern African Development Coordinating Conference (SADCC) adopted on 1 April 1980. (http://en.wikipedia.org/wiki/SADC).

The organization kicked off with nine members. Membership in the Frontline States and SADCC sometimes differed. Currently SADC comprises fourteen member countries namely Angola, 
Botswana, Democratic Republic of Congo, Lesotho, Mauritius, Madagascar, Malawi, Mozambique, Namibia, Swaziland, South Africa, Tanzania, Zambia and Zimbabwe. From the above submissions, it is therefore safe to argue that this evolving organization was a coterie of old friends bound by a common history and therefore bound to each other in many circumstances.

SADCC or the conference as it was known, was formed with four principal objectives, namely, (i) to reduce member states' dependence, particularly, but indeed not only, on Apartheid South Africa; (ii) to implement programmes and projects with national and regional impact; (iii) to mobilise member states' resources, in the quest for collective self-reliance; (iv) and to secure international understanding and support.

With the emanation of new problems and also the expansion in the membership (Namibia joined later), the SADCC was transformed into a more "relevant" organization aimed at socio-economic cooperation and political and security cooperation. On 17 August 1992 the founding fathers adopted the SADC Treaty. Subsequently, after the South African democratic elections in 1994, the Frontline States was dissolved. At that time subsequent efforts to place political and security cooperation on a firm institutional footing under SADC's umbrella failed.

(http://en.wikipedia.org/wiki/Southern_African_Development_Community).

On 14 August 2001, the 1992 SADC treaty was amended. The grouping adopted objectives that sought to show the changes envisaged by the member states. Its objectives were to:

1. Achieve development and economic growth, alleviate poverty, enhance the standard and quality of life of the people of Southern Africa and support the socially disadvantaged through regional integration;

2. Evolve common political values, systems and institutions;

3. Promote and defend peace and security;

4. Promote self-sustaining development on the basis of collective self-reliance, and the interdependence of member states;

5. Achieve complementarity between national and regional strategies and programmes;

6. Promote and maximise productive employment and utilisation of resources of the Region;

7. Achieve sustainable utilization of natural resources and effective protection of the environment;

8. Strengthen and consolidate the long standing historical, social and cultural affinities and links among the people of the Region.

The amendment heralded the overhaul of the structures, policies and procedures of SADC. One of the changes was that political and security cooperation was institutionalized in the Organ on Politics, Defense and Security (OPDS). It has been argued that as one of the principal SADC bodies, it became subject to the oversight of the organization's supreme body, the Summit, which comprises the heads of state or government. (http://en.wikipedia.org/wiki/Southern_African_Development_Community). However, it is clear that the principles that drive the organization have not been evolved. The new organs and policies, it would seem, only serve to protect heads of state chiefly because they are all from the liberation ruling parties.

One important objective of the SADC is its desire to promote and defend peace and security. This objective is also consolidated by another equally important objective that of evolving common political values, systems and institutions. The above objectives have been pursued across Southern Africa especially in conflict zones. But this has been done with mottled success particularly in Zimbabwe and the DRC. This can be explained by a few but very strong factors.

Firstly, there is no explicit objective in the SADC Treaty that predisposes it to effective conflict resolution. This means that, conflict resolution by the SADC is always only in pursuance of other objectives. In other words, conflict resolution for SADC is not an end in itself and neither is it a means to some end. It is simply an incidental adventure thrust upon SADC as the principal intergovernmental organization within that region. This is problematic because it does not empower SADC to make bold and legally binding decisions in conflict situations.

Secondly, SADC has been duplicated by a number of other regional organizations. Some member countries are not bound only by SADC but by other organizations within the same region. This undermines SADC. According to Wikipedia one significant challenge is that member states also participate in other regional economic cooperation schemes and regional political and security 
cooperation schemes that may compete with or undermine SADC's aims. For example, South Africa and Botswana both belong to the Southern Africa Customs Union (SACU), Zambia is a part of the Common Market for Eastern and Southern Africa (COMESA), and Tanzania is a member of the East African Community

(EAC). (http://en.wikipedia.org/wiki/Southern_African_Development_Community).

Thirdly, it is arguable that SADC's decisions are affected and influenced more by what can be said to be 'vague objectives' within its constitution which either make it difficult to take firm decisions in conflict resolution or to take wrong decisions altogether in pursuit of such skewed objectives. One example of such objectives is based on "strengthening and consolidating the long standing historical, social and cultural affinities and links among the people of the region". In pursuance of this objective, it is arguable, that SADC has made some dangerous decisions devoid of pragmatism, only pursuing comradeship.

\section{Theoretical framework}

Conflict resolution is a range of processes aimed at alleviating or eliminating sources of conflict. According to Wikipedia.com, the term conflict resolution is sometimes used interchangeably with the term dispute resolution. Processes of conflict resolution generally include negotiation, mediation and diplomacy. The processes of arbitration, litigation, and formal complaint processes such as ombudsman processes, are usually described with the term dispute resolution, although some refer to them as "conflict resolution." Processes of mediation and arbitration are often referred to as alternative dispute resolution. (http://en.wikipedia.org/wiki/Conflict_resolution).

There is considerable controversy about definitions and terminology in the field of conflict resolution. This may be partly because the field is multidisciplinary. Academics and practitioners are found within diverse disciplines including political science, international relations, law, and psychology. (http://en.wikipedia.org/wiki/Conflict_resolution).

Many of the definitional concerns spring from diverse definitions of the terms conflict and dispute and resolution. The term conflict has been defined as "intense interpersonal and/or intrapersonal dissonance (tension or antagonism) between two or more parties based on incompatible goals, needs, desires, values, beliefs, and/or attitudes." (Ting-Toomey: 1985) Disputes have been defined as conflicts that have become particularized around a specific issue or issues. (Abel: 1973). Some conflicts may not become manifest as articulated disputes. Thus, "conflict resolution" tends to refer to processes that address the sources of conflict so as to prevent them from escalating or eliminate the conflict altogether. The term "dispute resolution" refers to settlement of disputes and complaints, which may or may not address or eliminate the sources of the conflict. (http://en.wikipedia.org/wiki/Conflict_resolution). It is within this context that SADC's efforts in Zimbabwe can be understood. In Zimbabwe the whole situation can be characterized as dispute resolution to a larger extent but clearly, I find this very problematic especially as it fails to deal with the very causes of conflict.

There are many tools available to persons in conflict. How and when they are used depends on several factors (such as the specific issues at stake in the conflict and the cultural context of the disputants). The list of tools available to practitioners includes negotiation, mediation, community building, advocacy, diplomacy, activism, non-violence, critical pedagogy, prayer and counseling. In real world conflict situations, which range in scale from kindergarten bullying to genocide, practitioners will creatively combine several of these approaches as needed. Additionally, practitioners will often specialize in a particular scale (e.g. interpersonal, community or international), or a particular variety of conflict (such as environmental, religious or organizational), and repertoires of tools they find most useful. ((http://en.wikipedia.org/wiki/Conflict_resolution)

\section{Background to conflict in the DRC}

The current conflict in the DRC has its roots in the 1990s. After the Rwandan genocide of 1994, Congolese President Mobutu allowed the Interahamwe (a group of Hutus responsible for the genocide) to take refuge in the DRC. The interahamwe launched attacks into Rwanda from the Eastern Congo, triggering the Rwandan Army's invasion of the DRC. 
(http://www.getloud.ca/en/gpi_issues.asp?id=12). In 1996, the Rwandan and Ugandan-backed Alliance of Democratic Forces of Congo- Zaire (ADFL) marched on to Kinshasa. Mobutu fled, and Laurent-Kabila declared himself President. In July of 1998, Ugandan and Rwandan troops left the DRC at the request of Kabila; however, Rwandan troops invaded the DRC a few weeks later. (http://www.getloud.ca/en/gpi_issues.asp?id=12). Kabila turned to the Southern African Development Community (SADC) for help. Zimbabwe, Namibia and Angola sent troops to help ward of the Rwandan and Ugandan armies. By 1999, Rwanda, Uganda, and the Congolese rebel groups that they sponsored managed to control one third of the DRC.

In July 1999, the Lusaka Accord was signed by the six warring nations (Democratic Republic of Congo, Angola, Namibia, Zimbabwe, Rwanda, and Uganda) and rebel groups in an attempt to stop the civil war. The Lusaka Accord called for a cease-fire, the deployment of UN peacekeepers and the disarmament and repatriation of all armed foreign groups. Unfortunately, all parties have not consistently implemented the treaty.

Although officially there has been a cease-fire since 2003, intermittent fighting continues on the ground. In March 2004, there was an attempted coup against the government in Kinshasa. Throughout the war, many nations and multinational corporations have exacerbated the conflict by exploiting the DRC's rich natural resources for their own gain.

The largest war in modern African history, the Second Congo war, directly involved eight African nations including the DRC, Zimbabwe, Angola, Namibia, Uganda, and Rwanda, as well as about 25 armed groups. Most of the countries involved were member states of SADC. However, they were involved more on individual basis than under the SADC banner. What is more, some countries such as South Africa did not join to support the SADC countries. If anything, wide reports then were that they clandestinely supported the rebel armies.

As with most conflicts, civilians have suffered immensely. The International Rescue Committee (IRC) has attempted a few surveys during the conflict. The IRC found that since the war started in 1998:

1. Some 5.4 million people have died in this conflict, either by the bullet or other social consequences of the war

2. It has been the world's deadliest conflict since world war II

3. Although $19 \%$ of the population, children account for $47 \%$ of the deaths

4. Some 45,000 continue to die each month. (Shar:2008)

Oxfam also noted that "the international community is essentially ignoring what has been deemed 'Africa's first world war.' The DRC remains a forgotten emergency. Falling outside of the media spotlight, and experiencing persistent shortfalls in pledged humanitarian aid, the population of the DRC has been largely abandoned to struggle for their own survival." (Oxfam: 2000)

\section{Background to conflict in Zimbabwe}

The conflict in Zimbabwe dates back to around 1998, when the Mugabe regime embarked on a drive to win back its diminishing support base. Food riots, student demonstrations and workers' strikes had become the order of the day owing to economic meltdown in the country at the time. Also, the veterans of the liberation war were growing impatient with the government's unfulfilled promises namely restitution of land to the landless and recompense for their war efforts during Second Chimurenga. The crux of the matter: opposition to the government was swelling.

To salvage the slipping political support, Mugabe embarked on controversial policies both domestically and abroad. Abroad, he launched an unjustified intervention in the Democratic Republic of Congo. More than 11, 000 troops were committed to this cause. The intervention has been criticised for its insurmountable economic cost. At home the Mugabe regime embarked on populist and destructive policies to hang on to power.

Firstly, he angled for the appeasement of the veterans of the liberation war. To that end, he awarded unbudgeted gratuities of Z\$50, 000 each for their participation in the war. This induced untold economic shocks. The economy of Zimbabwe continued to slide sharply into recession. Opposition to Mugabe increased. 
Secondly, upping his populist tempo at home, Mugabe began the process of confiscating white owned farms. Party loyalists benefited. By the year 2000, the land reform exercise had taken a nasty route. White owners of land were violently displaced by party functionaries with reckless abandon.

In 1999, the Movement for Democratic Change (MDC) was born. The party was a culmination of people's struggles against a spiraling cost of living, against dictatorial tendencies by the regime and an innate and inescapable outcome of the third wave of democratization ${ }^{\mathrm{i}}$ in Africa, given the conducive conditions in Zimbabwe at the time. Unfortunately, the Mugabe regime instead of tackling the MDC as political opposition, they set on a war path to destroy the movement which they branded names such as, enemies of the state, puppets of the west, zvimbwasungata (surrogates of imperialism), gays of Tony Blair e.t.c. In the 2000 constitutional referendum, ZANU (PF) government was defeated by pro-opposition forces that were against a skewed draft constitution. Strictly speaking, the February 2000 plebiscite defeat ignited conflict between Mugabe and the opposition.

Since the June 2000 elections, Zimbabwe elections became axiomatically characterized by violence, accusations of gerrymandering, vote rigging and assassination plots. Mugabe's legitimacy was thrown into the abyss. Two points of power had emerged: on one hand was the neo-liberal MDC led by Morgan Tsvangirai and on the other hand the neo-nationalist ZANU (PF) led by Mugabe. Their confrontation climaxed with each major election. This called for intervention by the regional body, SADC.

\section{SADC in Zimbabwe and the Democratic Republic of Congo}

SADC mediation in Zimbabwe was conceived at an urgent SADC summit held in Tanzania in March 2002, when Thabo Mbeki (South African president) was appointed as mediator in the Zimbabwean crisis in order to manage her political crisis. The result area to this mediation was to help the two parties come to a political settlement after the preceding violent and divisive election. While SADC had shown the required leadership by focusing its attention on Zimbabwe, It is widely agreed that SADC failed in its judgements and decisions. This brings to the fore the question: Has the SADC role in Zimbabwe been actively positive or passively negative? Below I outline how SADC complicated rather than resolve problems faced by Zimbabweans.

SADC's efficacy in its dreary conflict resolution efforts in Zimbabwe can better be explained by a number of features. These can be précised as, but not relegated to, SADC's bond with ZANU (PF) and its leader Robert Mugabe, its pessimistic perception of the MDC and its President Morgan Tsvangirai, the intricate state of affairs in SADC member countries, and the facade of championing "Pan-Africanism". Below, I expound on each of these four factors and how they have largely prejudiced the conduct of SADC and therefore its disappointing performance in resolving the crisis in Zimbabwe.

Firstly, it is important to analyze the role of SADC in dealing with its member states from an understanding mentioned above: that it is a coterie of comradeship. Furthermore, the majority of SADC's membership is still ruled by Liberation War movements e.g. ANC in South Africa, SWAPO in Namibia, MPLA in Angola, FRELIMO in Mozambique and ZANU (PF) in Zimbabwe all of whom remain friends amongst and between themselves. These movements led uprisings against white supremacy in their countries. They organized against imperialism in this part of the continent. These movements successfully executed the struggle against colonialism through networking. Such a common history is to an outsized extent responsible for the decisions that SADC and its Heads of State have made. It is therefore not an exaggeration to affirm that their historical affinities far outweigh any present or future challenge to their hegemony as long as they exist.

According to Georgy, "SADC is made up of a group of leaders that are friends of President Mugabe. Many of them have been in power for a long time and do not respect democratic decisions,"(Michael Georgy, From Mail \& Guardian (SA), 11 November 2002). Evidence abounds to support the above assertion. The 2002 presidential elections were violently conducted in a mode that had not been experienced in the post independence epoch since the Matebeleland massacres. ZANU (PF) militias, partisan army and police and the secret agents were unleashed to brutalise all dissenting voices in a grotesque and unimaginable fashion. There was an international outcry to cease the violence. While the opposition, civic society, and international organizations such as the 
Commonwealth and European Union declared the presidential election as not free and fair, surprisingly, SADC and the African Union explicitly endorsed Mugabe regime's actions. In this manner it is with merit to argue that the SADC served only to appease a friend and legitimize a wholly and evidently violent, unfair and non-free election.

Secondly, since the emergence of the MDC in 1999, Mugabe and his party merchandised the idea that the Movement for Democratic Change and its President Morgan Tsvangirai were puppets of the west designed to effect regime change so as to "reinstitute" white imperial interests in the country. Peddling of such emotive and dangerous lies merited to invoke the sad memories of the armed liberation struggle and therefore win conservative support at home and the palpable buttress by regional leaders. That ruse seemed to stick even within the SADC. Ironically, Mbeki as leader of the regional power, South Africa, led all efforts to discredit Tsvangirai while at the same he was supposed to be an impartial SADC mediator. He played a major role in the 2005 MDC split. The above affirmation is corroborated by Maingire when he stated that: "On one side is the involvement of President Thabo Mbeki of South Africa in a plan to wrestle power from Morgan Tsvangirai and put the MDC under the control of Welshman Ncube... Mbeki is believed to be uncomfortable with a tradeunion backed opposition party unseating ZANU (PF) in a similar fashion to what became of Zambia when Fredrick Chiluba ousted Kenneth Kaunda. Mbeki finds a serious threat to his ANC political survival..." (R. Maingire, The Untold Story of the MDC, Thursday 9 August 2007, (The Zimbabwean.Com).

Morgan Tsvangirai was vividly aware of this negative perception and its consequent actions. He had suggested the same when he wrote to Mbeki, ... It was suggested that you were again in contact with a member of my National Executive, Secretary-General Mr. Tendai Biti. This interaction is reminiscent of that which happened prior to the break up of the MDC in October 2005.1 respectfully submit to you that such "private" meetings contributed to the misunderstandings that later led to a split in our organization... (http://www.thetimes.co.za/PrintEdition/PDFs/TsvangiraiLetter.pdf.)

Notwithstanding the above, it has remained that, the SADC regional leaders have leaned heavily against the democracy seeking Tsvangirai than they have rebuked the dictatorial Mugabe. It is not surprising that even when Tsvangirai won the March 2008 four-tier elections, which were endorsed as free and fair by SADC organizations and member states and the African Union and its organs, SADC heads of state chose to side with and cuddle Mugabe. Pressure was made to bear on Tsvangirai in all SADC mediation resolutions. A case in point was the ruling by SADC that the MDC co-manage a ministry with ZANU (PF), an unprecedented arrangement the world over. After the SADC summit Whande asserted that,

...instead of helping the people of Zimbabwe to regain their moral high ground and political imperative, SADC leaders are now ganging up against us. African leaders are a disgrace and SADC are worse. As is being confirmed by Somalia, Darfur, Zimbabwe and DR Congo, there are no African solutions to African problems. (T. Whande, http://www. swradioafrica.com).

Thirdly, the political state of affairs in the SADC member states can help better understand SADC decisions, and therefore its effectiveness or lack of the same in resolving the decade long political crisis in Zimbabwe. There remains a marked paucity of democratic practice within these member states. Swaziland, Lesotho, Namibia, The DRC, Angola and Malawi as cases have generated a lot of debate as to whether democracy can work in Africa. Allegations of election rigging, primitive rule (in Swaziland and Lesotho), armed conflict, stolen elections and lack of legitimacy by the leaders are negative benchmarks in southern African debate on democracy. These, no doubt, affect SADC decisions and effectiveness in her midwifery role to the rebirth of a peaceful and democratic southern Africa.

Lastly, "Pan-Africanism", across Africa, has been strategically used as a mask while depicting opposition parties as western surrogates, unpatriotic and therefore divisive. Pan-Africanism calls for a politically united Africa. (http://en.wikipedia.org/wiki/Pan-Africanism). In this vein, patriotism has been sequestrated, monopolized and personalized to mean automatic support of ruling parties and often times their antiquated philosophies, all of which are believed to be the repositories and champions of the African dream of a united Africa. MDC and its leaders have been major victims of 
this hoax while ZANU (PF) and its corrupt leaders have benefited from the same. This belief however should be fanatically challenged.

Opposition parties are health to any democratic dispensation. Firstly, they hold the executive to account. However, in Zimbabwe, this has made them enemies of government simply because they exposed all indecent government officials' activities. Secondly, they provide an alternative government. All citizens of a country should be allowed to choose whom they want or not to govern them. The Mugabe regime has resorted to dictatorship, where as an election loser on March 292008 , he clearly asserted that "the gun is mightier than the pen" referring to elections as means of choosing one's leaders. This was unpatriotic and a defeat of democracy.

It should therefore be asserted that no-one individual, group or society can monopolise patriotism. After all, it depends on who defines patriotism? For whom patriotism is defined? And for what purposes that patriotism is being defined by the same? We submit that patriotism is a value which is subjective when used against opposition. Opposition parties such as the MDC can equally be patriotic or even more patriotic than the ruling parties. For the MDC, they, represent aspirations of millions of Zimbabweans as reflected in the national elections where the MDC President won the confidence of the majority of all Zimbabweans.

According to Dahlen and Sandvand (2005) The DRC became a member of SADC in 1990, and the organization has been profoundly involved in the peacemaking efforts in the conflict. However soon after the ouster of former Zaire strongman, Mobutu Sese Seko and the ascension to power of Desire Laurent Kabila SADC was bound to be seriously seized with the task of conflict resolution in that country. In August 1998, the SADC Summit 'committed itself to seek an end to the military conflict immediately'. (http://www.sadc.int/archives/read/news/236).

However, since that time, the DRC conflict did not invite enough attention and collaborated effort by SADC countries in resolving the conflict. What has been identified is a incoherent and piecemeal attention to the conflict by a mother organization which is supposed to take a lead in the resolution of the conflict. A number of reasons can be proffered for this lackadaisical approach to solving issues in the region.

Firstly, it is the lack of trust for each other by the member states and some longstanding amityenmity dichotomies. This is corroborated by Francis who posited that, "SADC peacekeeping intervention... is based on ad hoc improvisation, often its deployment is based on flawed military assessment and driven by the amity-enmity of the geo-political co-operation." (Francis: 2006).

Struggles for regional dominance are a factor that cannot be underestimated in analyzing the reasons why SADC has not been effective in the conflict resolution in the DRC. Zimbabwe and postApartheid South Africa have been pitched for a long time in what can be aptly called a battle for regional dominance. According to Mutenheri (2009).

This rivalry protruded into the post apartheid era during Mandela's tenure. The relationship between South Africa and Zimbabwe degenerated into a political wrestling for control of the region. In 1997 Mandela and Mugabe had a highly publicized show-down over the status and functions of a regional security organization, the Organ on Politics, Defense and Security within SADC. Mugabe wanted the Organ to operate as an autonomous body under his control, something vehemently opposed by Mandela.

Mutenheri further noted that; This competition and battle for supremacy climaxed when Zimbabwe militarily intervened in the DRC in 1998. For South Africa this move by the Zimbabwe government, undertaken in the name of $S A D C$, was viewed as placing the organization in risk and challenged South Africa's leadership aspirations in the region. The two countries were also at odds over the participation of Congolese rebels in national peace talks, with Mandela favoring their inclusion but Mugabe dead set against it.

No doubt, the failure of SADC can also be explained by the fact that the DRC and its neighbors have not created conditions necessary for understanding. According to Whande, 'DR Congo has the luxury to present Africa with an encore of the mindless violence against itself with the help of other neighboring countries, not to mention Zimbabwe and Angola who are already in the DR Congo. (T. Whande: 2 November 2008) 
One could also argue that the geographical location of the DRC within the context of SADC has alienated her from SADC that it has brought her closer. DRC is more geographically divorced from the SADC member states and generally that expends the interest of the member states to fixate themselves with a member state which is so distant and does not provide any geo-political advantages.

\section{Conclusion}

From the foregoing it can be averred that the performance of SADC in conflict spots in the region is a hotchpotch of failure, 'lukewarm' results, malfunction and disenchantment. Where they have produced optimism, it has always been cautious. The dragging and prolonging of resolution processes by SADC has been driven by such factors as the desire to please fellow leaders, struggles for regional dominance, and failure to reform, aspects devoid of any principle. The efficacy of SADC measured on the criteria of relevance, effectiveness, sustainability, principle and pragmatism is still a far cry from achieving the goals for which it was formed, particularly conflict resolution. SADC as evidenced by its decisions, actions and involvement in Zimbabwe has shown that it is still hostage to past heroworship of liberators like Mugabe oblivious of the fact that the region should be progressive to embrace the aspirations and values of a free world based on democratic values. The emphases here being that SADC should take the lead to rein in errant leaders, enforce democratic principles and ensure sustainability of the same. The performance of SADC in DRC has also raised questions as to whether the organization is relevant or is part of the problems in the countries concerned. The divisions in approaches to deal with the conflict and the droopy approach to intervention put paid to the widely held belief that SADC is a toothless dog devoid of strategies for conflict resolution in the region. There is therefore need for a paradigm shift by SADC if it is to deal decisively with tyrants and avert escalation of conflicts in the region.

\section{References}

[1]. Dahlen. I. A. S, SADC and the war in the Democratic republic of Congo: a critical view on the role of a regional organization in a conflict-torn memberstate, I.A.S. Dahlen, 2005, 82.

[2]. Feddious Mutenheri, South-South Co-operation or Sub-Imperialism: South African "Quiet" Diplomacy, SADC Docility, and the Underdevelopment of Zimbabwe. Journal of Sustainable Development in Africa. (unpublished).

[3]. Francis. D, Uniting Africa: Building Regional Peace and Security Systems, 2006, Google Books.com.

[4]. Oxfam, A Forgotten War-A Forgotten Emergency: The Democratic Republic of Congo, a Policy Paper, December 2000, provides many details and statistics, as well as criticism of the lack of international support.

[5]. Richard Abel, "A Comparative Theory of Dispute Institutions in Society" (1973) 8 Law \& Society Review 217 at 217.

[6]. Shah. A, The Democratic Republic of Congo, Global Issues, Thursday, March 27, 2008.

[7]. Stella Ting-Toomey et. al, "Toward a Theory of Conflict and Culture." In Communication, Culture and Organizational Processes, Thousand Oaks, CA: Sage, 1985, at 72.

[8]. http://en.wikipedia.org/wiki/SADC.

[9]. http://en.wikipedia.org/wiki/Southern_African_Development_Community.

[10]. http://en.wikipedia.org/wiki/Conflict_resolution.

[11]. (http://www.getloud.ca/en/gpi_issues.asp?id=12).

[12]. http://www.thetimes.co.za/PrintEdition/PDFs/TsvangiraiLetter.pdf.

[13]. http://www.swradioafrica.com.

[14]. http://www.sadc.int/archives/read/news/236).

${ }^{\mathrm{i}}$ Feddious Mutenheri is a Zimbabwean and tutor in Development Studies at Livingstone Kolobeng College, Box 403388, Block 8, Gaborone, Botswana. Cell: +26775092190, e-mail: feddious@gmail.com

${ }^{i}$ Third wave of Democratization refers to what is considered by some to be democratic transitions and democratization throughout much of the developing world. The phrase however, has come under criticism, largely by those who stress that so called democratic transitions are little more than 
Texila International Journal of Academic Research Volume 6, Issue 1, Apr 2019

transitions to semi-authoritarian rule, as demanded by the international realities of a post-cold war world. 